\title{
Bacteriological Quality Assessment of Hand-dug Shallow Water Wells in Awka Metropolis, Anambra State, Nigeria
}

\author{
Onuorah Samuel*, Elesia Rosemary, Odibo Frederick \\ Department of Applied Microbiology and Brewing, Nnamdi Azikiwe University, Nigeria
}

Copyright $\subset 2016$ by authors, all rights reserved. Authors agree that this article remains permanently open access under the terms of the Creative Commons Attribution License 4.0 International License

\begin{abstract}
Bacteriological quality assessment of some hand-dug shallow water wells in Awka metropolis was carried out during the dry and wet seasons to determine their potability. The total bacterial, total coliform, faecal coliform and Vibrio chloreae counts were determined using standard laboratory methods. The total bacterial counts during the dry season ranged from 100 to $300 \mathrm{cfu} / 100 \mathrm{ml}$; total coliform counts, $42-126 \mathrm{cfu} / 100 \mathrm{ml}$; faecal coliform counts, $10-26$ $\mathrm{cfu} / 100 \mathrm{ml}$ and Vibrio cholerae counts, $2-10 \mathrm{cfu} / 100 \mathrm{ml}$. During the wet season, the total bacterial counts ranged from 148 to $450 \mathrm{cfu} / 100 \mathrm{ml}$; total coliform counts, $77-240$ $\mathrm{cfu} / 100 \mathrm{ml}$; faecal coliform counts, $12-30 \mathrm{cfu} / 100 \mathrm{ml}$ and Vibrio cholerae counts, $6-13 \mathrm{cfu} / 100 \mathrm{ml}$. The bacteria isolated during the dry season were Salmonella typhi (7.44\%), Proteus vulgaris (18.08\%), Pseudomonas aeruginosa (27.55\%), Enterobacter aerogenes (35.71\%), Vibrio cholerae $(2.85 \%)$ and Escherichia coli $(8.37 \%)$. During the wet season, the bacterial isolates were Salmonella typhi (6.14\%), Proteus vulgaris (14.56\%), Pseudomonas aeruginosa (21.69\%), Enterobacter aerogenes (29.70\%), Vibrio cholerae (3.66\%), Escherichia coli (8.23\%) and Klebsiella pneumoniae (16.03\%). All the water wells studied were of poor bacteriological quality. Appropriate water purification methods should therefore be developed for such wells to avert a public health hazard.
\end{abstract}

Keywords Bacteriological, Quality, Assessment, Hand-dug, Shallow Wells, Awka Metropolis

\section{Introduction}

Water is one of the most important and abundant compounds in the ecosystem. All living organisms on the earth need water for their survival and growth. The earth is the only planet having about $70 \%$ of water. Water is used for an array of activities such as drinking, food preparation and sanitation. In as much as safe drinking water is essential to health, a community lacking a good quality of it will be saddled with lots of health problems which could otherwise be avoided [1].

Access to adequate safe drinking water is of prime importance to many governmental and international organizations since it is the core component of primary health care and a basic component of human development as well as precondition of man's success to deal with hunger, poverty and death [2].

Many regions of the world are already limited by the amount and quality of available water. Accessible water is unlikely to increase more than ten percent in the next thirty years alone but the earth's population is projected to rise by approximately one third. Unless the efficiency of water use rises, this imbalance will reduce quality water services, reduce the conditions of health of the people and deteriorate the environment and the world [3].

The water cycle is an obvious mode of transmission of enteric diseases [4]. Almost 385,000 children die annually of various diseases due to polluted water. Polluted water is potentially dangerous to health because of possible outbreaks of water-borne diseases. A large variety of bacterial, viral and protozoan pathogens are capable of initiating water borne infections. Some are primarily the enteric bacterial pathogens such as Vibrio cholerae, Salmonella spp, Shigella spp, Campylobacter jejuni and Entero haemorrhagic E. coli. The survival potential of these bacteria increases in biofilms $[5]$.

The presence of microorganisms is of great importance in the water industry with regards to water-borne diseases. Some of such diseases are dysentery, typhoid fever, paratyphoid fever, cholera, infantile paralysis, infectious hepatitis, guinea worm and amoebic dysentery [6]. Transmission of the causative micro-pathogenic organisms is through direct or indirect contamination of water source by human excreta. Since it is extremely difficult to isolate and identify different forms of pathogens, the microorganisms which are of significance to water quality are those of enteric pathogenic origin [6].

Raw water many contain a wide variety of microorganisms such as Flavobacterium spp, Pseudomonas spp, Acinetobacter spp, Moraxella spp, Chromobacterium spp, Achromobacter spp and Alcaligenes spp as well as 
numerous unidentified or unidentifiable bacteria [7]. Traditionally, the microbiological quality of drinking water is assessed by monitoring non-pathogenic bacteria of faecal origin [8,9]. Microorganisms commonly used as indicators of water quality include coliforms, faecal Streptococci, Clostridium perfringens and Pseudomonas aeruginosa [10].

Majority of the residents of Awka metropolis depend on shallow hand-dug wells as the major source of water for drinking and domestic purposes. Though most of these wells are usually covered, they may not be free from contamination from runoff percolating into them through cracks. Sanitary risk inspection also showed that many of the wells are located close to septic tanks and animals rearing houses. Regular bacteriological analysis of the water from these shallow wells are therefore crucial to safeguard the health of the residents from water-borne diseases, therefore in this study, the bacteriological quality of some hand-dug shallow water wells in Awka metropolis was assessed.

\section{Materials and Methods}

\subsection{Collection of Water Samples}

Fifteen hand-dug shallow water wells in Okpuno Awka, Ifite Awka, Okperi Awka, Umuogbu Awka, Ogbengwu Awka, Umuokpu Awka, Umunagu Awka, Sugarline Amansea, Ngo Amansea, Omeluora Close Amansea, Okoye Close Amansea, Orji Avenue Amansea, Akurulo Avenue Amansea, Obi Avenue Amansea and Kenneth Close Amansea all in Awka metropolis were assessed bacteriologically during the dry and wet seasons. Five samples were each collected from each of the wells in January, February and March (dry season) while the same number of samples were also collected from each of the wells in July, August and September (wet season) in 2016.

The samples were collected aseptically in sterilized and legibly-labeled $200 \mathrm{ml}$ plastic containers with screw caps at a depth of two meters with a strong twine tied around the containers. The samples were thereafter transported to the Microbiology laboratory of Nnamdi Azikiwe University, Awka in an ice box within one hour of collection.

\subsection{Membrane Filtration Apparatus Set Up}

A vacuum pump was connected to a sterile filtration unit. The funnel of the filtration unit was removed and a sterile smooth-tipped forceps was used to collect the membrane filter paper (Millipore Corporation, England) which was thereafter placed onto the porous disc of the filter base. The sterile funnel was carefully replaced on the filter base.

\subsection{Bacteriological Analysis}

The total bacterial, total coliform, faecal coliform and Vibrio cholerae counts were carried out as done by Cheesbrough [11].

One hundred millilitres of a water sample were passed through a membrane filter and the filter aseptically placed with the grid side uppermost on already prepared and sterilized nutrient agar, MacConkey agar, Eosin methylene blue agar and Thiosulphate citrate bile salt sucrose agar for the total bacterial, total coliform, faecal coliform and Vibrio cholerae counts. The media were contained in petri-dishes. Duplicate plates were prepared and incubation was carried out at $28^{\circ} \mathrm{C}$ for 24 hours for the total bacterial count and $28^{\circ} \mathrm{C}$ for the 48 hours for the total coliform, faecal coliform and Vibrio cholerae counts after which the bacterial colonies that grew were counted and the result expressed as colony forming unit per $100 \mathrm{ml}$. Each colony was sub-cultured on sterile nutrient agar plates and later stored on sterile nutrient agar slants for characterization and identification.

\subsubsection{Characterization and Identification of the Isolates}

The isolates were characterized morphologically, biochemically and molecularly. Gram staining, catalase, coagulase, motility, oxidase, indole, methyl red, voges proskaeur, urease, hydrogen sulphide production and sugar (glucose, sucrose and lactose) fermentation tests were performed as carried out by Onuorah et al [12]. The isolates were identified with the scheme of Krieg and Holt [13].

\subsection{Data Analysis}

The data were subjected to correlation analysis using SPSS 8.0 package to determine the level of significance between the bacteriological parameters.

\section{Results}

The bacteriological analysis (total bacterial count, total coliform count, faecal coliform count and Vibrio cholerae count) of the hand-dug shallow wells water samples during the dry season is presented in Table 1 . The total bacterial counts were from 100 to $300 \mathrm{cfu} / 100 \mathrm{ml}$, total coliforms, $42-126 \mathrm{cfu} / 100 \mathrm{ml}$, faecal coliforms, $10-26 \mathrm{cfu} / 100 \mathrm{ml}$ and Vibrio cholerae, $2-10 \mathrm{cfu} / 100 \mathrm{ml}$. 
Table 1. Bacteriological Analysis of the Hand-dug Shallow Wells Water Samples during the Dry Season

\begin{tabular}{|c|c|c|c|c|c|}
\hline Sample & Well Location & $\begin{array}{c}\text { Total bacterial } \\
\text { count }(\mathrm{cfu} / 100 \mathrm{ml})\end{array}$ & $\begin{array}{c}\text { Total coliform } \\
\text { count }(\mathrm{cfu} / 100 \mathrm{ml})\end{array}$ & $\begin{array}{l}\text { Faecal coliform } \\
\text { count }(\mathrm{cfu} / 100 \mathrm{ml})\end{array}$ & $\begin{array}{l}\text { Vibrio cholerae } \\
\text { (cfu/100ml) }\end{array}$ \\
\hline 1. & Okpuno Awka & 200 & 84 & 15 & 7 \\
\hline 2. & Ifite Awka & 280 & 118 & 23 & 2 \\
\hline 3. & OKperi Awka & 150 & 63 & 21 & 6 \\
\hline 4. & Umuogbu Awka & 240 & 101 & 17 & 10 \\
\hline 5. & Ogbengwu Awka & 261 & 114 & 12 & 8 \\
\hline 6. & Umuokpu Awka & 200 & 86 & 19 & 9 \\
\hline 7. & Umunagu Awka & 300 & 126 & 15 & 4 \\
\hline 8. & Sugarline Amansea & 100 & 42 & 13 & 4 \\
\hline 9. & Ngo Amansea & 150 & 60 & 11 & 6 \\
\hline 10. & Omeluora Close Amansea & 250 & 105 & 20 & 8 \\
\hline 11. & Okoye Close Amansea & 133 & 72 & 26 & 7 \\
\hline 12. & Orji Avenue Amansea & 130 & 96 & 10 & 6 \\
\hline 13. & Akurulo Avenue Amansea & 200 & 80 & 14 & 4 \\
\hline 14. & Obi Avenue Amansea & 100 & 45 & 11 & 8 \\
\hline 15. & Kenneth Close- Amansea & 210 & 88 & 16 & 4 \\
\hline \multicolumn{2}{|r|}{ WHO Standard } & 100 & 0 & 0 & 0 \\
\hline
\end{tabular}

The bacteriological analysis (total bacterial count, total coliform count, faecal coliform count and the Vibrio cholerae count) of the hand-dug shallow wells water samples during the wet season is shown in Table 2 . The total bacterial counts were $148-450 \mathrm{cfu} / 100 \mathrm{ml}$; total coliform count, $77-240 \mathrm{cfu} / 100 \mathrm{ml}$; faecal coliform count, 12-30 cfu/100ml and Vibrio cholerae count, $6-13 \mathrm{cfu} / 100 \mathrm{ml}$.

Table 2. Bacteriological Analysis of the Hand-dug Shallow Wells Water Samples during the Wet Season

\begin{tabular}{|c|c|c|c|c|c|}
\hline Sample & Well Location & $\begin{array}{c}\text { Total bacterial } \\
\text { count }(\mathrm{cfu} / 100 \mathrm{ml})\end{array}$ & $\begin{array}{c}\text { Total coliform } \\
\text { count }(\mathrm{cfu} / 100 \mathrm{ml})\end{array}$ & $\begin{array}{l}\text { Faecal coliform } \\
\text { count (cfu/100ml) }\end{array}$ & $\begin{array}{c}\text { Vibrio cholerae } \\
\text { (cfu/100ml) }\end{array}$ \\
\hline 1. & Okpuno Awka & 275 & 148 & 17 & 10 \\
\hline 2. & Ifite Awka & 320 & 171 & 26 & 8 \\
\hline 3. & OKperi Awka & 170 & 90 & 24 & 9 \\
\hline 4. & Umuogbu Awka & 264 & 143 & 20 & 13 \\
\hline 5. & Ogbengwu Awka & 270 & 150 & 18 & 9 \\
\hline 6. & Umuokpu Awka & 257 & 136 & 25 & 10 \\
\hline 7. & Umunagu Awka & 450 & 240 & 19 & 9 \\
\hline 8. & Sugarline Amansea & 148 & 77 & 17 & 7 \\
\hline 9. & Ngo Amansea & 186 & 100 & 16 & 8 \\
\hline 10. & Omeluora Close Amansea & 300 & 160 & 23 & 10 \\
\hline 11. & Okoye Close Amansea & 170 & 125 & 30 & 11 \\
\hline 12. & Orji Avenue Amansea & 230 & 115 & 12 & 8 \\
\hline 13. & Akurulo Avenue Amansea & 280 & 149 & 18 & 6 \\
\hline 14. & Obi Avenue Amansea & 172 & 86 & 21 & 9 \\
\hline 15. & Kenneth Close- Amansea & 252 & 130 & 22 & 10 \\
\hline & WHO Standard & 100 & 0 & 0 & 0 \\
\hline
\end{tabular}

The morphological and biochemical characteristics of the bacterial isolates in the hand-dug shallow wells water samples during the dry and wet seasons are presented in Table 3. The isolates were identified as Salmonella typhi, Proteus vulgaris, Pseudomonas aeruginosa, Enterobacter aerogenes, Vibrio cholerae, Escherichia coli and Klebsiella pneumoniae. 
Table 3. Morphological and Biochemical Characteristics of the Bacterial Isolates from the Hand-dug Shallow Wells Water Samples during the Dry and Wet Seasons

\begin{tabular}{|c|c|c|c|c|c|c|c|c|c|c|c|c|c|c|c|c|}
\hline Isolate & $\begin{array}{l}\text { Gram } \\
\text { Stain }\end{array}$ & form & $\begin{array}{l}\text { Catelase } \\
\text { test }\end{array}$ & $\begin{array}{l}\text { Coagulase } \\
\text { test }\end{array}$ & $\begin{array}{l}\text { Motility } \\
\text { test }\end{array}$ & $\begin{array}{l}\text { Oxidase } \\
\text { test }\end{array}$ & $\begin{array}{l}\text { Indole } \\
\text { test }\end{array}$ & $\begin{array}{l}\text { Methyl } \\
\text { red test }\end{array}$ & $\begin{array}{l}\text { Voges } \\
\text { proskaer } \\
\text { test }\end{array}$ & $\begin{array}{l}\text { Urease } \\
\text { test }\end{array}$ & $\begin{array}{c}\text { Citrate } \\
\text { Utilization } \\
\text { test }\end{array}$ & $\begin{array}{l}\text { Hydrogen } \\
\text { sulphide } \\
\text { production } \\
\text { test }\end{array}$ & $\begin{array}{c}\text { Glucose } \\
\text { fermentation } \\
\text { test }\end{array}$ & $\begin{array}{c}\text { Sucrose } \\
\text { fermentation } \\
\text { test }\end{array}$ & $\begin{array}{c}\text { Lactose } \\
\text { fermentation } \\
\text { test }\end{array}$ & Identity \\
\hline 1 & - & Rod & + & - & + & - & - & + & - & - & + & + & + & - & - & $\begin{array}{c}\text { Salmonella } \\
\text { typhi }\end{array}$ \\
\hline 2 & - & Rod & + & - & + & - & + & + & + & + & - & + & + & + & - & $\begin{array}{l}\text { Proteus } \\
\text { vulgaris }\end{array}$ \\
\hline 3 & - & Rod & + & - & + & + & - & - & - & - & - & - & - & - & - & $\begin{array}{c}\text { Pseudomonas } \\
\text { aeruginosa }\end{array}$ \\
\hline 4 & - & Rod & + & - & + & - & - & - & + & - & + & - & + & + & + & $\begin{array}{c}\text { Enterobacter } \\
\text { aerogenes }\end{array}$ \\
\hline 5 & - & Rod & + & - & + & + & - & - & + & - & - & - & + & + & - & Vibrio cholerae \\
\hline 6 & - & Rod & + & - & + & - & + & + & - & - & - & - & + & + & + & Escherichia coli \\
\hline 7 & - & Rod & + & - & - & - & - & - & + & + & + & - & + & + & + & $\begin{array}{c}\text { Klebsiella } \\
\text { pneumoniae }\end{array}$ \\
\hline
\end{tabular}

$+=$ Positive reaction

$=$ Negative reaction 
Table 4. Number of Hand-dug Shallow Water Wells with the Bacterial Isolates during the Dry and Wet Season Seasons

\begin{tabular}{|c|c|c|}
\hline Bacterial Isolates & $\begin{array}{c}\text { Number of Wells with the Isolates during dry } \\
\text { season }\end{array}$ & $\begin{array}{c}\text { Number of wells with the isolates during } \\
\text { wet Season }\end{array}$ \\
\hline Salmonella typhi & $6(40.00 \%)$ & $9(60.00 \%)$ \\
\hline Proteus vulgaris & $7(46.67 \%)$ & $8(53.33 \%)$ \\
\hline Pseudomonas aeruginosa & $8(53.33 \%)$ & $10(66.67 \%)$ \\
\hline Enterobacter aerogenes & $15(100.00 \%)$ & $15(100.00 \%)$ \\
\hline Vibrio cholera & $15(100.00 \%)$ & $15(100.00 \%)$ \\
\hline Escherichia coli & $15(100.00 \%)$ & $15(100.00 \%)$ \\
\hline Klebsiella pneumoniae & $0(0.00 \%)$ & $7(46.67 \%)$ \\
\hline
\end{tabular}

Table 5. Frequency of Occurrence of the Bacterial isolates in the Hand-dug Shallow Wells Water Samples during the Dry and Wet Seasons

\begin{tabular}{|c|c|c|}
\hline Bacterial Isolates & $\begin{array}{c}\text { Number of Colonies Isolated during the dry } \\
\text { season }\end{array}$ & $\begin{array}{c}\text { Number of Colonies Isolated during the } \\
\text { wet season }\end{array}$ \\
\hline Salmonella typhi & $216(7.44 \%)$ & $230(6.14 \%)$ \\
\hline Proteus vulgaris & $525(18.08 \%)$ & $545(14.56 \%)$ \\
\hline Pseudomonas aeruginosa & $800(27.55 \%)$ & $812(21.69 \%)$ \\
\hline Enterobacter aerogenes & $1037(35.71 \%)$ & $1112(29.70 \%)$ \\
\hline Vibrio cholerae & $83(2.85 \%)$ & $137(3.66 \%)$ \\
\hline Escherichia coli & $243(8.37 \%)$ & $308(8.23 \%)$ \\
\hline Klebsiella pneumoniae & $0(0.00 \%)$ & $600(16.03 \%)$ \\
\hline Total & $2,904(100.00 \%)$ & $3,744(100.00 \%)$ \\
\hline
\end{tabular}

The number of hand-dug shallow water wells with the bacterial isolates during the dry and wet seasons is shown in Table 4. Salmonella typhi, Proteus vulgaris, Pseudomonas aeruginosa, Enterobacter aerogenes, Vibrio cholerae and Escherichia coli were detected in $40.00 \%, 46.67 \%, 53.33 \%$, $100.00 \%, 100.00 \%$ and $100.00 \%$ of the water wells respectively during the dry season while Salmonella typhi, Proteus vulgaris, Pseudomonas aeruginosa, Enterobacter aerogenes, Vibrio cholerae, Escherichia coli and Klebsiella pneumoniae were isolated from $60.00 \%, 53.33 \%, 66.67 \%$, $100.00 \%, 100.00 \%, 100.00 \%$ and $46.67 \%$ of the water wells respectively during the wet season.

The frequency of occurrence of the bacterial isolates in the hand-dug shallow wells water samples during the dry and wet seasons is presented in Table 5. Enterobacter aerogenes had the highest frequency of occurrence of $35.71 \%$ while Vibrio cholerae had the lowest frequency of occurrence of $2.85 \%$ in the samples during the dry season. Enterobacter aerogenes also had the highest frequency of occurrence of $29.70 \%$ while Vibrio cholerae had the lowest frequency of occurrence of $3.66 \%$ during the wet season.

\section{Discussion}

The total bacterial count is used to estimate the total number of bacteria in water. The count was more during the wet season than during the dry season due to the fact that rain water carrying microorganisms must have infiltrated into the wells. Obiri-Danso et al [14] studied the microbiological quality of wells in some peri-urban communities in Kumasi, Ghana and reported that significantly higher bacterial counts were recorded during the wet (rainy) season compared to the dry (harmattan) season. Most of the samples contained bacteria in excess of the recommended limit of $100 \mathrm{cfu} / 100 \mathrm{ml}$ (Tables 1 and 2). This result agreed with that of Okonko et al [15] who reported that all the water samples used for domestic purposes in Abeokuta, Ogun State and Ojota, Lagos State which they analyzed had high total bacterial counts exceeding the WHO limit.

The total coliform counts, faecal coliform counts and Vibrio cholerae counts were above the WHO recommended limit (Tables 1and 2) indicating that the samples were polluted. More total coliforms, faecal coliform and Vibrio cholerae were isolated during the wet season than during the dry season. This may be attributable to the seepage of flood harbouring faeces into the wells through cracks. Many of the wells were also located near septic tanks and household drainage systems. The result indicated that the samples were polluted recently with faeces of human or animal origin and agreed with Okonko et al [15] that reported the presence of 5-48 faecal coliforms in the water samples they analyzed.

Muhammad [16) carried out an assessment of ground water quality in low income high density areas of Kaduna metropolis and reported that over $65 \%$ of the samples were contaminated by coliforms. Taiwo et al [17] carried out the bacteriological analyses of well water in Abeokuta metropolis, Ogun State, Nigeria and reported that the total coliform count ranged from 10 to $20 \times 10^{5} \mathrm{cfu} / \mathrm{ml}$. They also reported that all the water samples showed high 
concentration of Escherichia coli in excess of the stipulated limit of zero.

The bacterial isolates from the water samples were Salmonella typhi, Proteus vulgaris, Pseudomonas aeruginosa, Enterobacter aerogenes, Vibrio cholerae Escherichia coli and Klebsiella pneumoniae (Table 3). Romulus et al [18] also isolated Salmonella, Escherichia coli, Vibrio, Enterobacter, Klebsiella and Pseudomonas from the shallow wells in Kitui Town, Kenya. Okonko et al [15] also isolated and identified Salmonella species, Escherichia coli, Pseudomonas aeruginosa, Enterobacter aerogenes, Proteus species and Klebsiella species in the different water samples used for domestic purposes in Abeokuta, Ogun State and Ojota, Lagos State in Nigeria. Adeyomo et al [19] investigated the water quality of twelve wells in a major abattoir in Bodija in Ibadan, Nigeria and reported that they were highly contaminated with pathogenic bacteria including Escherichia coli, Pseudomonas aeruginosa and Enterobacter aerogenes.

Salmonella typhi, Proteus vulgaris and Pseudomonas aeruginosa were detected in $40.00 \%, 46.67 \%$ and $53.33 \%$ of the water wells respectively while Enterobacter aerogenes, Vibrio cholerae and Escherichia coli were each detected in $100.00 \%$ of the water samples examined during the dry season (Table 4). Salmonella typhi, Proteus vulgaris, Pseudomonas aeruginosa and Klebsiella pneumoniae were detected in $60.00 \%, 53.33 \%, 66.67 \%$ and $46.67 \%$ of the wells respectively while Enterobacter aerogenes, Vibrio cholerae and Escherichia coli were each detected in all the samples examined during the wet season (Table 4). Aydin [20] assessed the microbiological quality of ground water in West Thrace, Turkey and reported that the total coliforms, thermotolerant coliforms, E. coli, Salmonella $s p$ and Pseudomonas aeruginosa were detected in 25\%, $17.5 \%$, $15 \%, 15 \%$ and $15 \%$ of the ground water samples respectively. Pavendan et al [21] carried out the microbial assessment of drinking water from different water sources of Tiru Chirappalli district, South India and reported that microbial pollution was recorded in $11.1 \%$ of the open wells studied.

Enterobacter aerogenes was the predominant bacterium isolated from the water samples during both seasons (Table 5) with a frequency of occurrence of $35.71 \%$ during the dry season and $29.70 \%$ during the wet season while Vibrio cholerae had the lowest frequency of occurrence of $2.85 \%$ during the dry season and $3.66 \%$ during the wet season.

Salmonella typhi can be found both in warm and cold-blooded animals and is a gram negative bacterium and a strong pathogen that causes systemic infections and typhoid fever in humans. It has caused many deaths in developing countries where sanitation is poor and is spread chiefly through contaminated water. The bacterium invades the surface of the human intestine, the deeper tissues of the spleen, liver and bone marrow. Symptoms include a sudden onset of high fever, headache, nausea, loss of appetite, diarrhoea and enlargement of the spleen [22]. Their presence in the water samples may be attributed to contamination from septic tanks, wastewater and animal droppings.
Proteus vulgaris is a rod shaped, gram negative bacterium that inhabits the intestinal tracts of humans and animals. It can be found in the soil polluted water and faecal matter. It is an opportunistic pathogen of humans that causes wound infections, urinary tract infections, severe abcesses and nosocomial infections [23].

Pseudomonas aeruginosa is a gram negative, rod shaped, asporogenous bacterium and an opportunistic human and plant pathogen. Shallow ground water samples commonly contain Pseudomonas spp. which also occurs in soil, humans, animals, plants and faecal materials. The ability of the bacterium to thrive in harsh conditions contributes to its being widespread in nature. Pseudomonas infection is the second most common infection in hospitalized persons and the presence of Pseudomonas aeruginosa in water is a potential problem for immune compromised individuals with cystic fibrosis, cancer or AIDS [24].

Enterobacter aerogenes is a gram negative, rod-shaped bacterium commonly found in soil, water and dairy products. It forms part of the endogenous human gastrointestinal microflora. They are numerous in faecal materials than other bacteria and more resilient in non-enteric environments, which may have accounted for the bacteria being more often detected and at a higher concentration in ground water samples than the thermotolerant Escherichia coli. It is responsible for infections in hospitals and is a cause for concern in community infections. It is a frequent cause of infections in immuno compromised individuals and those with serious underlying health conditions. It has been implicated in urinary tract infections, skin and soft tissue infections, bacteremia, low birth weight and premature babies [25].

Vibrio cholerae is a comma shaped, gram negative bacterium that causes the pandemic disease cholera. It infects the intestine and increases mucous production causing diarrhoea and vomiting which result in profuse dehydration and death if left untreated. It thrives in water and is transmitted to humans through faecally-polluted water, particularly in economically reduced areas without good water purification systems [26]. The fact that it was detected in all the water samples is a serious public health problem.

Escherichia coli bacteria live in the intestines of humans and animals. Most E. coli are harmless but some are pathogenic and cause gastroenteritis, urinary tract infections and neonatal meningitis. The diarrhoea causing $E$. coli can be transmitted through contaminated water. The presence of $E$. coli in water indicates that the water may be contaminated by human or animal waste. Faecal-oral transmission is the major route through which the pathogenic strains of this bacterium cause diseases. Water with coliforms or Escherichia coli is not safe for drinking. The presence of faecal coliform may be an indicator of recent faecal pollution which suggests access to undesirable materials and could constitute a potential public health hazard to the consumers of such water [15].

Klebsiella pneumoniae is a gram negative, rod shaped and facultatively anaerobic human pathogen. It is commonly 
found in the gastrointestinal tract, hands of hospital personnel, surface water, sewage and soil [27]. Diseases caused by the bacterium include urinary tract infections, pneumonia, septicemias, and soft tissue infections [28]. The diseases can result in death for patients who are immunodeficient. The bacterium was not detected in the samples during the dry season probably because it produces capsular (K) antigens which are easily destroyed by heat thereby affecting its survival.

The total bacterial counts, total coliform counts and Vibrio cholerae counts had correlation ranges of $6.382,6.194$ and 6.295 respectively during the dry and wet seasons which were significant at 5\% significance level while the faecal coliform counts had a correlation range of 0.000 which was insignificant at 5\% significance level using t-distribution. All the shallow hand-dug water wells sampled during both seasons were polluted with coliforms, Vibrio cholerae and other bacteria which are known to be pathogenic to humans. Their presence may be attributed to the dumping of domestic wastes within the vicinity of the wells, closeness of the wells to septic tanks and drainage systems and the nearness of animal breeding houses to the wells, therefore the water from such wells must be subjected to adequate treatment to protect the health of the consumers in the area.

\section{Conclusions}

The water samples assessed were of poor bacteriological quality. Most of them from both seasons were contaminated with potential pathogens which may pose serious risk to public health and safety. The values for the total bacteria, total coliforms, faecal coliforms and Vibrio cholerae indicated shallowness and the poor sanitary conditions of the wells, therefore it is absolutely necessary to treat the water wells before use by humans to avoid an outbreak of water-borne diseases. Residents of the area should be enlightened on the need for proper disposal of wastes in designated areas. Refuse dumping sites, pit latrines and septic tanks should be sited at safe distance from the wells. In addition, the wells water should be subjected to periodic bacteriological analyses to confirm their potability.

\section{REFERENCES}

[1] G. T. Miller. Environmental Science Working with the earth. $6^{\text {th }}$ edition, Wadsworth publishing company, USA. Pp. 285-286, 1997.

[2] World Health Organization. Guideline for drinking water quality. $3^{\text {rd }}$ Edition, WHO Press Geneva, Switzerland. Pp. 398, 2006.

[3] World Health Organization. Global water supply and sanitation assessment. WHO press Geneva, Switzerland. Pp. $110,2000$.
[4] M.M. Hutchinson, Ridgeway. Microbial agent of drinking water supplies. Aquatic microbiology, Shewan and Stainer edition, Society of Applied Bacteriological Technical Services, Vol. 10. No.9, Pp. 70-80, 1997.

[5] J.T. Wilson, J.F. Mcnabb, D. Balkwill, W.C. Ghiorse. Enumeration and characterization of bacteria indigenous to a shallow water-table aquifer. Ground water. Vol. 21, No.2, 134-142, 1983. DOI:10.1111/j.1745-6584.1983.t500710.x.

[6] U. Szewzyk, R. Szewzyk, W. Manz, K.H. Schleifer. Microbiological safety of drinking water. Annual Review of Microbiology. Vol. 54, 81-127, 2000. DOI:10.1146/annurev. micro.54.1.81.

[7] J. Kolbel-Boeke, B. Tieken, A. Nehrkorn. Microbial communities in the saturated ground water environment. Methods of isolation and the characterization of heterotrophic bacteria. Microbial Ecology, Vol. 16, No. 1, 17-29, 1988. doi:10.1007/BF02097402

[8] W.A.M. Hijnen, D.A. Van-Veendaal, W.M.H. Van der Speld, A. Vissers, W. Hoogenboezem, D. Van der Kooji. Environmental assessment of faecal indicator bacteria in large water volumes using on-site membrane filtration to assess water treatment efficiency. Water Research, Vol. 34, No. 5, 1659-1665, 2000. DOI: 10.1016/S0043-1354 (99)00311-5.

[9] A. Rompre, P. Servais, J. Baudart, M.R. De Roubin, P. Laurent. Detection and enumeration of coliforms in drinking water. Current methods and emerging approaches. Journal of microbiological methods, Vol. 49, No. 1, 31-54, 2002. www.ncbi.nlm.nih.gov/pubmed/11777581.

[10] K.M. Elizabeth, L. Premnath Naik. Determination of physicochemical parameters of surface water. Pollution Research, Vol. 24, No. 2, 337-340, 2005.

[11] M. Cheesbrough. District laboratory practicals in tropical countries. $2^{\text {nd }}$ edition, Cambridge University Press, United Kingdom, Pp 35-70, 2006.

[12] S. Onuorah, M. Orji, I. Obika. Microbial contamination of electrical power transformer oil obtained from Onitsha, Nigeria. Bioengineering and Bioscience, Vol. 4, No. 2, 24-28, 2016. DOI: 10.13189/bb.2016.040203.

[13] N.R. Krieg, J.G. Holt. Bergey's manual of systematic bacteriology. William and Wilkins, Baltimore Ltd, U.S.A Pp 60-70. 1994

[14] K. Obiri-Danso, B. Adjei, K.N. Stanley, K. Jones. Microbiological quality and metal levels in wells and boreholes water in some peri-urban communities in Kumasi, Ghana. African Journal of Environmental Science and Technology. Vol. 3, No.1, 059-066, 2009. DOI:10.5897/AJEST08.126.

[15] I.O. Okonko, O.D. Adejoye, T.A. Ogunnusi, E.A. Fajobi, O.B. Shittu. Microbiological and physicochemical analysis of different water samples used for domestic purposes in Abeokuta, Ogun State and Ojota, Lagos State, Nigeria. African Journal of Biotechnology. Vol. 7, No.5, 617-621, 2008. http://www.academicjournals.org/AJB.

[16] M.N. Muhammad. Assessment of ground water quality in low income high density areas of Kaduna metropolis. Academic Research International, Vol. 2, No. 1, 183-190, 2012. www.savap.org.pk. 
[17] A.A. Taiwo, T.O. Ijaola, O. Jiboku, I. Oluwadare, A. Osunkiyesi. Physicochemical and bacteriological analyses of well water in Abeokuta metropolis, Ogun-State, Nigeria. IOSR Journal of Applied Chemistry, Vol. 2, No.6, 29-35, 2012. www.iosrjournals.org.

[18] A. Romulus, M. Mutemi, M. Eunice, M. Kennedy, M. Mutinda, M. M. Cecilia. Physicochemical and bacteriological quality assessment of shallow wells in Kitui town Kenya. Journal of Environmental Science and Water Resources. Vol. 1, No.2, 27-33, 2012.

http://www.wudpeckerresearchjournals.org/JESWR.

[19] O.K. Adeyemo, I.O. Ayodeji, C.O. Aiki-Raji. The water quality and sanitary conditions in a major abattoir (Bodija) in Ibadan, Nigeria. African Journal of Biomedical Research, Vol. 5, 51-55, 2002.

https://tspace.library.utoronto.ca/bitstream/1807/2223/1/md0 2010.

[20] A. Aydin. The microbiological and physicochemical quality of ground water in West Thrace, Turkey. Polish Journal of Environmental Studies, Vol. 16, No.3, 377-383, 2007. http://www.researchgate.net/publication/289247594.

[21] P. Pavendan, S.A. Selvan, C.S. Rajasekaran. Physicochemical and microbial assessment of drinking water from different water sources of Tiruchir- appalli district, South India. European Journal of Experimental Biology. Vol. 1, No.1, 183-189, 2011. www/pelagiaresearchlibrary.com.

[22] D.M Monack, A. Muller, S. Falkow. Persistent bacterial infections: the interface of the pathogen and the host immune system. Nature Reviews Microbiology. Vol. 2, No. 9, 747-765, 2004. DOI:10.1038/nrmicro955.
[23] C.M. O’ Hara, F.W. Brenner, J.M. Miller. Classification, identification and clinical significance of Proteus, Providencia and Morganella. Clinical Microbiology Reviews, Vol. 13, No.4, 534-546, 2000. DOI:10.1128/CMR.13.4.534546.2000 .

[24] K. Botzenhart, G. Doring. Ecology and epidemiology of Pseudomonas aeruginosa. Pseudomonas aeruginosa as an opportunistic pathogen. Pp. 1-18, 1993. DOI: 10.1007/978-1-4615-3036-7_1.

[25] W.E. Sanders Jr, C.C. Sanders. Enterobacter spp: pathogens poised to flourish at the turn of the century. Clinical microbiology Reviews. Vol. 10, No. 2, 220-241, 1997. https://www.researchgate.net/publication/14111533.

[26] S.M. Faruque, M. J. Albert, J.J. Mekalanos. Epidemiology, genetics and ecology of toxigenic Vibrio cholerae. Microbiology and Molecular Biology Reviews, Vol.62, No. 4, 1301-1314, 1998.

https://www.ncbi.nlm.nih.gov/pubmed/9841673.

[27] S. Brisse, J. Verhoef. Phylogenetic diversity of Klebsiella pneumoniae and Klebsiella oxytoca clinical isolates revealed by randomly amplified polymorphic DNA, gyrA and parC genes sequencing and automated ribotyping. International Journal of Systematic and Evolutionary Microbiology. Vol. 51, No.3, 915-924, 2001. DOI:10.1099/00207713-51-3-915.

[28] R. Podschun, U. Ullmann. Klebsiella spp as nosocomial pathogens: epidemiology, taxonomy, typing methods and pathogenicity factors. Clinical Microbiology Reviews, Vol. 11, No.4, 589-603, 1998. www.ncbi.nlm.nih.gov/pubmed/9767057. 